\title{
Integrin Alpha-V Beta-3-Matrix Metalloproteinase-2 (MMP-2), Cross-Talk
}

\author{
Hrishikesh Sil ${ }^{1}$, Amitava Chatterjee ${ }^{2 *}$ \\ ${ }^{1}$ Department of Receptor Biology \& Tumor Metastasis Chittaranjan National Cancer \\ Institute, Kolkata, India \\ ${ }^{2}$ Ramakrishna Mission Vivekananda University (IRDM), Narendrapur, Kolkata, India \\ Email: hrishikesh.sil@gmail.com, ${ }^{*}$ urenuschatterjee@gmail.com
}

Received 26 June 2015; accepted 25 August 2015; published 28 August 2015

Copyright (C) 2015 by authors and Scientific Research Publishing Inc.

This work is licensed under the Creative Commons Attribution International License (CC BY). http://creativecommons.org/licenses/by/4.0/

(c) (i) Open Access

\section{Abstract}

The present study aimed to detect comparative expression of integrin $\alpha_{\mathrm{v}} \beta_{3}$ and its involvement in expression and activation of matrix metalloproteinase-2 (MMP-2) in 25 malignant human breast tumor and adjacent normal breast tissues from different clinical TNM stages (DCIS to T4) of the disease and possible involvement of known regulating parameters of MMP-2 like TIMP-2, MT1MMP and EMPRIN. Integrin $\alpha_{\mathrm{V}} \beta_{3}$ was highly expressed in tumors than adjacent normal breast tissues. Pro-MMP-2(72-KD) was mainly expressed in adjacent normal tissues compared to tumors. The mature forms of MMP-2 (68 KD and $64 \mathrm{KD}$ ) were found only in tumors. Appreciable expression of TIMP-2 and induction of MT1-MMP and EMPRIN in T2-T4 stages suggested their possible role in MMP-2 activation. Over expression Integrin $\alpha \mathrm{V} \beta 3$ in tumors than adjacent normal breast tissues was an indication of cancer progression with involvement of integrin signaling. We conclude that, the co-precipitation of MMP-2 with $\alpha_{\mathrm{v}} \beta_{3}$ by anti- $\alpha_{\mathrm{v}}$ antibody is a strong indication that integrin $\alpha_{\mathrm{v}} \beta_{3}$ is a surface receptor for MMP-2 and $\alpha_{\mathrm{v}} \beta_{3}$-MMP-2 complex on the surface of tumor cells may play a very important role in determining the invasive property and malignant behavior of tumor tissues. The positive expression of endogenous inhibitor of MMP-2, TIMP-2 may have an appreciable role in activation of this protease and risk of malignancy in advanced stage of the disease. The enhanced expression of MT1-MMP and EMPRIN suggested a role for these factors in gelatinase regulation. However the exact mechanism(s) remains to be investigated. Finally, evaluation of integrin $\alpha_{\mathrm{v}} \beta_{3}$ associated MMP-2 expression and activity may add valuable information and can possibly be therapeutic target. The clinical exploitation of integrins will provide oncologists with novel therapeutic strategies for the treatment of malignancy in breast cancer.

\footnotetext{
*Corresponding author.
} 
Keywords

Breast Cancer, MMP-2, Alpha V Beta3, MT1-MMP, TIMP-2, EMPRIN, VEGF

\section{Introduction}

Integrins are transmembrane heterodimeric proteins, consisting of noncovalently associated $\alpha(120-180 \mathrm{KD})$ and $\beta(90-110 \mathrm{KD})$ subunits [1] [2]. Integrins mediate cellular adhesion to and migration on the ECM proteins found in intracellular spaces and basement membrane [3]. They also regulate cellular entry into and withdrawal from cell cycle [4] [5]. Ligation of integrin by their ECM ligands induces a cascade of intracellular signals [6] that include tyrosine phosphorylation of focal adhesion kinase (FAK), increment of intracellular $\mathrm{Ca}^{2+}$ levels, ionositol lipid synthesis, synthesis of cyclins [5] and expression of intermediate early genes [6]. In contrast, prevention of integrin ligand interaction suppress cellular growth and induces apoptotic cell death [7] [8]. Integrin on tumor cells are now thought to play intricate role in the progression of solid tumors. Integrin expression is altered in malignant cells as compared to their normal counter parts and altered integrin expression appears to be involved in several aspects of tumor growth, invasion and metastasis [9]. One of the most studied integrin receptors in tumor progression and metastasis is $\alpha_{\mathrm{v}} \beta_{3}$ which is a major integrin for vitronectin and plays important role in cancer growth. In murine cells, interaction of vitronectin with its receptor provides co-mitogenic signal [10]. Malignant melanomas express these integrin receptors as they enter the vertical growth phase [11]. Upregulation of this receptor in endothelial cells facilitates their interaction with lung carcinoma cells indicating a potential role of this receptor in tumor cell extravasations [12]. Tumorogenicity in athymic nude mice strongly correlated with $\alpha_{\mathrm{v}} \beta_{3}$ expression by tumor cells [13].

Cellular invasion process involves the production of proteolytic enzymes which are capable of degrading components of the extra cellular matrix and basement membrane. One of the major groups of these enzymes is matrix metalloproteinase (MMP) family. The prognostic value of MMPs has been investigated in several malignancies. The role of MMP-2, is well established during invasive activity of many cell types [14]-[16]. In particular, the molecular interaction between MMP-2 and integrin $\alpha_{v} \beta_{3}$, via the hemopexin C (PEX) domain, was shown to be essential for efficient cell invasion and angiogenesis [17] [18]. MMP-2 overexpression has been correlated with poor survival in breast carcinoma [19] [20] especially in node-positive patients. Studies reveal that the $\alpha_{\mathrm{v}} \beta_{3}$ integrin receptor is expressed by various cancer types. Malignant melanoma has been shown to modulate expression of proteolytic enzymes by the tumor cells. Stimulating antibodies to $\alpha_{\mathrm{v}} \beta_{3}$ in melanoma cell line caused increased expression of MMP-2 with an enhanced ability to invade basement membrane [21]. Expression of $\alpha_{\mathrm{v}} \beta_{3}$ on cultured melanoma cells enabled their binding to MMP-2 in a proteolytically active form, facilitating cell-mediated collagen degradation, thereby facilitating directed cellular invasion [17]. Integrin alpha $\mathrm{V}$ beta 3 was strongly expressed in primary invasive breast carcinomas. In contrast, this integrin heterodimer was abundant in all breast cancer cells metastatic to bone. In situ hybridization also revealed high levels of $\alpha_{v} \beta_{3}$ mRNA expression and suggested that integrin $\alpha_{v} \beta_{3}$ is an endothelial cell marker with significant prognostic value and potential usefulness as a target for specific anti angiogenic therapy. It also has been demonstrated that tumor-specific $\alpha_{\mathrm{v}} \beta_{3}$ contributes to spontaneous metastasis of breast tumors to bone and suggests a critical role for this receptor in mediating chemotactic and haptotactic migration towards bone factors. Our present study aimed to detect the comparative expression and activity of integrin $\alpha_{v} \beta_{3}$ associated MMP-2 in breast tumor tissue and adjacent normal breast tissue and the possible involvement of MT1-MMP, EMPRIN and TIMP-2 in the modulation of MMP-2 activity in breast cancer.

\section{Patients and Methods}

\subsection{Patients}

The present study involving 25 breast cancer patients diagnosed among the women, who were referred to Chittaranjan National Cancer Institute, India because of clinical breast lump, suspicious mammographic finding or a breast symptom (eq. pain, nipple discharge) between 2008 and 2010. Women willing to participate in the project were interviewed and examined by a trained study nurse before any diagonostic procedures. The participation rate of patients with diagonosed breast cancer was $98 \%$. Thus the patient series represents unselected typical 
breast cancer cases of different stages from the institutional hospital catchment area. Patients were offered treatment according to the stage of the disease, either surgery followed by chemotherapy and \pm Radiotherapy or Neo-adjuvant chemotherapy followed by surgery then completion chemotherapy and radiation depending on the mode of the surgery, the patient's menopausal status, and the stage of the disease, according to the national guidelines. In brief, postoperative radiotherapy was given to all patients treated with breast-conservation surgery. Hormonal therapy was offered to receptor ER or PR positive patients with axillary node positive ( $\mathrm{pN}+$ ) or T3 and T4 tumors irrespective of the mode of surgery. All pre-menopausal patients were treated with TabletTamoxifen for 5 years. Post menopausal patients were either treated for $2-3$ years with tamoxifen followed by 2 - 3 years of aromatase inhibitor or with aromatase inhibitor for 5 years. Patients with $\mathrm{pN}+$ status and some with axillary node negative ( $\mathrm{pN}-$ ) status presenting with other adverse prognostic factors such as estrogen receptor (ER)/progesterone receptor (PR) negative or poorly differentiated tumor, were given adjuvant chemotherapy (FEC/FAC cyclophosphamide, anthracyclin, taxens, methotrexate and 5-flurouracil) for six cycles. Stage was assessed by using the TNM classification. Patients with noninvasive carcinomas, a previous history of breast cancer, metastatic disease (stage-IV), or insufficient tumor material was excluded from the present study. Thus 81 patients with sufficient primary tumors and complete clinical histories were available for the present study. The mean age of the patients was 59.2 years (median 56.8 years; range, 23.3 - 91.6 years). The mean follow up time was 55.0 months (median 57.5 months; range, 1.2 - 115.1 months). The clinicopathological data of the patients are summarized in Table 1.

\subsection{Materials}

Gelatin Sepharose 4B beads was purchased from GE Healthcare Bio-Sciences AB, Uppsala, Sweden. All primary antibodies (anti-TIMP-2, anti-VEGF, anti-MT-1MMP, anti EMPRIN and, anti- $\beta$-tubulin) antibodies were purchased from Santa Cruz, USA. Biotinylated secondary antibodies, SuperSignal West Femto Maximum Sensitivity Substrate were purchased from Thermo Scientific, Rockford, USA. Avidin-biotinylated peroxidase complex reagent (vectastain Rabbit ABC kit) was purchased from vector laboratories, Burlingame, CA). Immobilon-P Membrane, (PVDF), was purchased from Millipore, USA.

\subsection{Methods}

Collection of tissue samples: Tissues from tumor and respective normal breast tissues of the same patient were collected from the operation theater during surgery. Tissues were stored at $-80^{\circ} \mathrm{C}$ and used for the further experiments.

Immunoprecipitation: Tissues of tumor samples and respective normal breast tissues of the same patient were collected, homogenized, extracted with tissue extraction buffer (Tris-50 mM, NaCl-150 mM, NP40-1\%, protease inhibitor cocktail and $\mathrm{pH}$ adjusted to 7.5) and the protein content of the extracts were estimated by Lowry's method. Equal amount of protein (100 $\mu \mathrm{g}$ each) of tissue lysate was pre cleared with Gelatin Sepharose $4 \mathrm{~B}$ beads shaking for 1 hour at $4^{\circ} \mathrm{C}$ and then subjected to co immunoprecipitation with anti- $\alpha \mathrm{v}$ monoclonal antibody $(1 \mu \mathrm{g} / \mathrm{ml})$ for overnight shaking at $4^{\circ} \mathrm{C}$. Antigen-antibody complexes are then bound to Gelatin Sepharose 4B beads (Roche). The beads were washed with $\times 3$ with Tris-buffered saline with (0.02\%) Tween-20 (TBST) and suspended in $50 \mu \mathrm{l}$ of $1 \times$ sample buffer ( 0.075 gm Tris, $0.2 \mathrm{gm} \mathrm{SDS}$ in $10 \mathrm{ml}$ water, $\mathrm{pH} 6.8)$ for $30 \mathrm{mins}$ at $37^{\circ} \mathrm{C}$. The extract was then subjected to zymography.

Gelatin Zymography: Equal amount of protein $(100 \mu \mathrm{g}$ each) of tissue lysate was taken. The gelatinases were separated from tissue extract using Gelatin Sepharose $4 \mathrm{~B}$ beads shaking for 2 hours at $4{ }^{\circ} \mathrm{C}$. The beads were washed $\mathrm{x} 3$ with Tris-buffered saline with (0.02\%) Tween-20 (TBST) and suspended in $50 \mu \mathrm{l}$ of $1 \times$ sample buffer $\left(0.075 \mathrm{gm}\right.$ Tris, $0.2 \mathrm{gm}$ SDS in $10 \mathrm{ml}$ water, $\mathrm{pH}$ 6.8) for $30 \mathrm{mins}$ at $37^{\circ} \mathrm{C}$. The extract was then subjected to zymography on $7.5 \%$ SDS-PAGE (sodium dodecyl sulfate polyacrylamide gel electrophoresis) co-polymerized with $0.1 \%$ gelatin. Gel was washed in $2.5 \%$ Triton-X-100 for 30 mins to remove SDS and was then incubated overnight in reaction buffer ( $50 \mathrm{mM}$ Tris- $\left.\mathrm{HCl} \mathrm{pH} \mathrm{7,} 4.5 \mathrm{mM} \mathrm{CaCl}_{2}, 0.2 \mathrm{M} \mathrm{NaCl}\right)$. After incubation, the gel was stained with $0.5 \%$ coomassie blue in $30 \%$ methanol and $10 \%$ glacial acetic acid. The bands were visualized by destaining the gel with $30 \%$ methanol and $10 \%$ glacial acetic acid.

Immunoblot assay: The tissues were collected, extracted with cell extraction buffer (Tris-37.7 mM, NaCl-75 $\mathrm{mM}$, Triton X-100-0.5\%, protease inhibitor cocktail and $\mathrm{pH}$ adjusted to 7.5 ) and the protein content of the extracts were estimated by Lowry's method. Equal amount of protein (50 $\mu \mathrm{g}$ each) was taken and co-immuno- 
Table 1. clinicopathological data of the patients.

\begin{tabular}{|c|c|}
\hline Characteristics & n (\%) \\
\hline No of patients & $25(100)$ \\
\hline \multicolumn{2}{|l|}{ Age (y) } \\
\hline Mean (range) & $57.3(23.1$ - 77.6) \\
\hline \multicolumn{2}{|l|}{ Tumor Size } \\
\hline $\mathrm{T} 2$ & $7(28)$ \\
\hline T3 & $10(40)$ \\
\hline $\mathrm{T} 4$ & $8(32)$ \\
\hline \multicolumn{2}{|l|}{ Lymph Node Status } \\
\hline Negative & $7(28)$ \\
\hline Positive & $18(72)$ \\
\hline \multicolumn{2}{|l|}{ Stage } \\
\hline II & $12(48)$ \\
\hline III & $13(52)$ \\
\hline \multicolumn{2}{|l|}{ Histological Type } \\
\hline Ductal & $23(92)$ \\
\hline Lobular & $2(8)$ \\
\hline \multicolumn{2}{|l|}{ Histological Grade } \\
\hline II & $10(40)$ \\
\hline III & $15(60)$ \\
\hline \multicolumn{2}{|l|}{ ER Status } \\
\hline Positive & $11(44)$ \\
\hline Negative & $14(56)$ \\
\hline \multicolumn{2}{|l|}{ PR Status } \\
\hline Positive & $9(36)$ \\
\hline Negative & $16(64)$ \\
\hline \multicolumn{2}{|l|}{ Her-2 Status } \\
\hline Positive & $19(76)$ \\
\hline Negative & $6(24)$ \\
\hline \multicolumn{2}{|l|}{ Menopausal Status } \\
\hline Pre menopausal & $20(80)$ \\
\hline Post Menopausal & $5(20)$ \\
\hline
\end{tabular}

precipitated with anti alpha-V antibody, heated with 0.1 volumes $\beta$-mercaptoethanol for 5 - 8 mins at $80^{\circ} \mathrm{C}-90^{\circ} \mathrm{C}$ was subjected to electrophoresis on $10 \%$ SDS-PAGE. The proteins were electrophoretically transferred on to Immobilon-P Membrane, (PVDF). membranes. The membranes were blocked with 1\% BSA and subsequently washed $\times 3$ with PBST. The membranes were reacted with anti-MMP-2(2C1) and anti- $\beta$-tubulin antibody antibody.

Equal amount of protein ( $50 \mu \mathrm{g}$ each) from tissue lysate was heated with 0.1 volumes $\beta$-mercaptoethanol for 5 - 8 mins at $80^{\circ} \mathrm{C}-90^{\circ} \mathrm{C}$ and subjected to electrophoresis on $7.5 \%$ SDS-PAGE. The proteins were electrophoretically transferred on to Immobilon-P Membrane, (PVDF). membranes. The membranes were blocked with $1 \%$ BSA and subsequently washed $\times 3$ with PBST. The membranes were reacted with anti-alpha-v, anti-MT-1MMP (L15), anti EMPRIN (8D6) and anti- $\beta$-tubulin antibody at 1/2000 dilution with 4\% BSA each and kept at 
$37^{\circ} \mathrm{C}$ for 1 hour 30 mins and subsequently washed $\times 3$ with PBST. The blots were developed using respective horse redish peroxidase (HRP) coupled second antibodies at $1 / 2000.00$ dilution and kept at $37^{\circ} \mathrm{C}$ for 1 hour 30 mins, the blots were then thoroughly washed $\times 6$ with PBST. Bands were visualized using SuperSignal West Femto Maximum Sensitivity Substrate [22]-[29].

Quantification of the results: Bands of zymography, western blots and RT-PCR were quantitated using Image J Launcher (version 1.4.3.67)

\subsection{Statistical Analyses}

The statistical analyses were carried out by using the Epi Info (TM) 3.5.3 software of the centers for disease Control and Prevention (CDC, USA) for windows 9.0 programme. The associations between MMP-2 expression and clinicopathological parameters were tested. The univariate analyses were performed using test of proportion, was carried out to find out the association of MMP-2 with molecular parameters including age, menopausal status, lymph node involvement, status of ER, PR, Her-2/neu and stage of the disease. Values of the parameters were expressed as Mean \pm s.e. and "p" values less than 0.05 were considered statistically significant.

\section{Results}

\subsection{Integrin $\alpha_{v} \beta_{3}$ Is Highly Expressed in Breast Cancer Tissue}

Comparative western blot analysis of malignant (TNM stage-T2-T4) breast tumor tissue and adjacent normal breast tissue lysate clearly shows that integrin $\alpha_{\mathrm{v}} \beta_{3}$ surface receptors are over expressed in tumor when compared to adjacent normal tissue (Figure 1).

The tissues were collected, extracted with NP40 extraction buffer (Tris-50 mM, NaCl-150 mM, NP40-1\%, protease inhibitor cocktail and $\mathrm{pH}$ adjusted to 7.5) and the protein content of the extracts were estimated by Lowry's method. Equal amount of protein (100 $\mu \mathrm{g}$ each) was taken. Pre-cleared and then subjected to co-immunoprecipitation following the method described in Methods \& Materials. Bands were visualized using SuperSignal West Femto as substrate.

\subsection{Breast Cancer Tissue Has More $\alpha_{v} \beta_{3}$ Associated MMP-2 Activity}

Comparative zymographic analysis of malignant (TNM stage-T2-T4) breast tumor tissue and adjacent normal breast tissue lysates, co-immunoprecipitated with anti $\alpha_{\mathrm{v}}$ monoclonal antibody clearly shows that gelatinolytic activity of pro-MMP-2(72) has been observed mainly in adjacent normal breast tissue lysate $(\mathrm{p}=0.00001)$. Where as in most of the tumor samples, subsequent proteolytic activation of this protease also has been observed

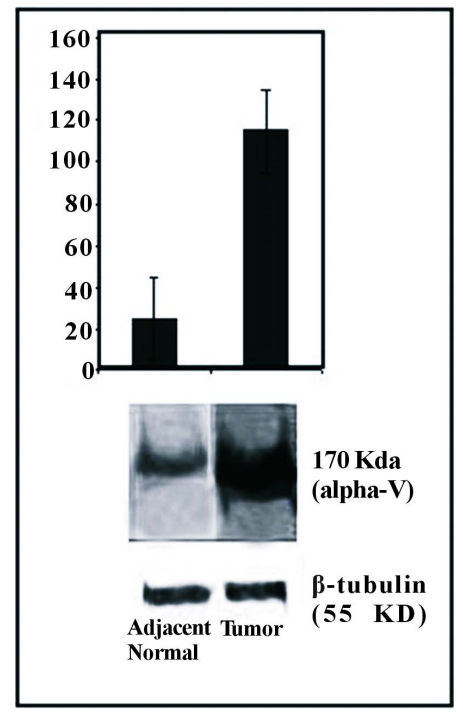

Figure 1. Expression of integrin $\alpha_{\mathrm{v}}$ in tumor \& adjacent normal breast tissue by immunoblot. 
in the form of gelatinolytic band of activated MMP-2 (68 KD and $64 \mathrm{KD})$. Though there was no significant difference of MMP-2 activity in TNM stage-II and III (T2-T4) (Figure 2).

Equal amount of protein (100 $\mu \mathrm{g}$ each) from Tissues of tumor samples (lane-T) and respective adjacent normal breast tissues (lane-N) of the same patient were taken. Pre-cleared with Gelatin Sepharose 4B beads shaking for 1 hour at $4^{\circ} \mathrm{C}$ and then subjected to co immunoprecipitation with anti- $\alpha_{\mathrm{v}}$ monoclonal antibody $(1 \mu \mathrm{g} / \mathrm{ml})$ following methods described in the text. The accompanying graph represents the comparative densitometric/quantitative analysis of the band intensities using image J Launcher (version 1.4.3.67).

\subsection{Breast Cancer Is Associated with Enhanced Expression of Integrin $\alpha_{\mathrm{v}} \beta_{3}$ Associated MMP-2}

Comparative western blot analysis of malignant (TNM stage-T2-T4) breast tumor tissue and adjacent normal breast tissue lysates, co-immunoprecipitated with anti- $\alpha \mathrm{V}$ monoclonal antibody clearly shows that total protein expression of pro-MMP-2 (72KD) has been appreciably increased in tumor tissue lysates as compared to adjacent normal breast tissue (Figure 3).

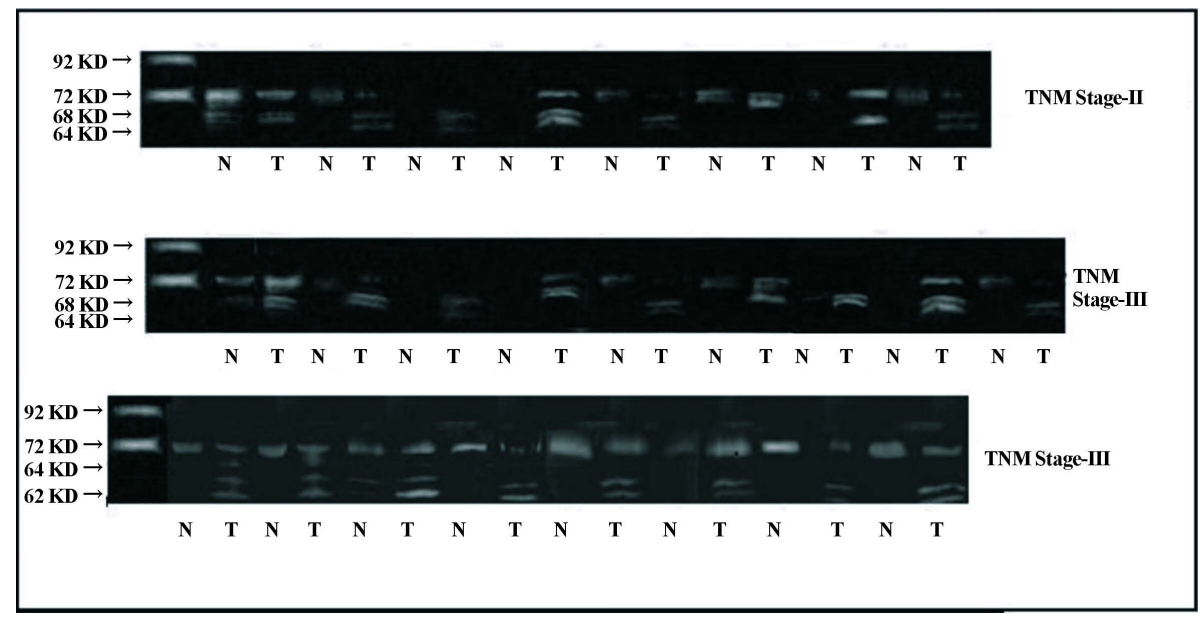

Figure 2. Zymographic analysis for gelatinolytic activity of $\alpha_{\mathrm{v}} \beta_{3}$ associated MMP-2 in breast tumor and adjacent normal tissue.

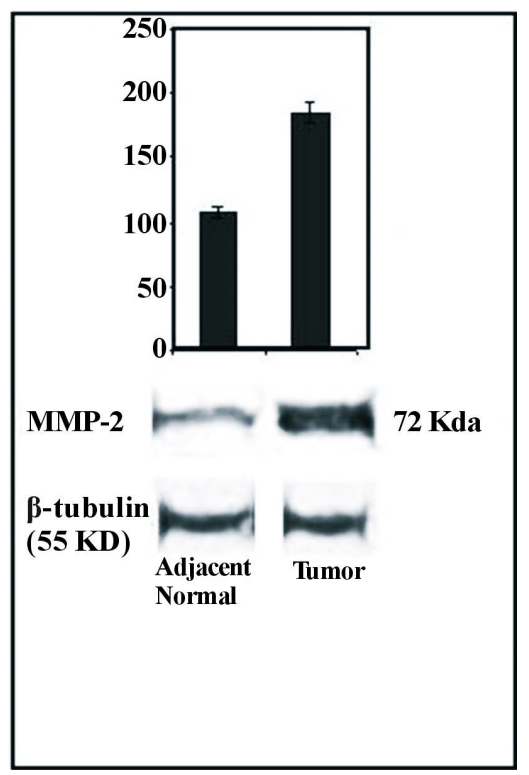

Figure 3. Expression of integrin $\alpha_{\mathrm{v}} \beta_{3}$ associated MMP-2 in tumor and adjacent normal tissue. 
The tissues were collected, extracted with NP40 extraction buffer (Tris-50 mM, NaCl-150 mM, NP40-1\%, protease inhibitor cocktail and $\mathrm{pH}$ adjusted to 7.5) and the protein content of the extracts were estimated by Lowry's method. Equal amount of protein (100 $\mu \mathrm{g}$ each) was taken. pre cleared with Gelatin Sepharose 4B beads shaking for 1 hour at $4^{\circ} \mathrm{C}$ and then subjected to co-immunoprecipitation with anti- $\alpha \mathrm{V}$ monoclonal antibody (1 $\mu \mathrm{g} / \mathrm{ml}$ ) for overnight shaking at $4^{\circ} \mathrm{C}$ following methods described in the text. Bands were visualized using SuperSignal West Femto as substrate. The accompanying graph represents the comparative densitometric/quantitative analysis of the band intensities using image J Launcher (version 1.4.3.67).

\section{Discussion}

In this present communication we have tried to elucidate the role of alfaVbeta3 integrin receptor in binding and activation of MMP-2 from 25 screened invasive breast cancer patients. The most pronounced difference was seen in zymographic analysis where we found gelatinolytic activity of activated forms of MMP-2 (i.e., the $68-\mathrm{kDa}$ and $64 \mathrm{kDa}$ ) were more frequent in tumor than the precursor form and were more intense than that corresponding to pro-gelatinase A (72 kDa). This fully active form of MMP-2 was not observed in adjacent normal breast tissue samples. Our findings are in agreement with other studies suggesting that the activation of MMP-2 (gelatinase A) is a more common event in aggressive breast cancer and integrin $\alpha_{\mathrm{v}} \beta_{3}$ is also responsible for this proteolytic activation of MMP-2 [30]-[33]. We observed progelatinase A in very few of tumor samples. There is strong evidence that shows integrin ligand interaction initiates a cascade of signaling reactions which induces the release of different proteases that dissolve the basement membrane and help in cell invasion. The enhanced expression of MMP-2 upon $\alpha_{\mathrm{v}} \beta_{3}$ ligation was demonstrated by Bufetti et al. [34]. As the cancer progressed from DCIS into T4stage, there was a tendency towards an increment of the gelatinolytic activity of MMP-2 which becomes significantly higher with subsequent activation of this protease in comparison to non-malignant breast tissue indicating the involvement of surface receptor integrin $\alpha_{\mathrm{v}} \beta_{3}$ in different stages of tumor progression and metastasis. MMP activity is tightly regulated at several levels, from transcription, to proenzyme activation and finally by inhibition with TIMPs. Most MMPs are secreted in a proenzyme form that is later activated by cleavage of the amino-terminal 80 amino acids. This processing to an active form is accomplished by one of the five membrane-type (MT) MMPs residing on the cell surface, by activated protein C, or by the plasminogen activator-plasminogen cascade [35]-[37]. A final step in regulating active MMPs is inhibition by small inhibitory proteins called TIMPs. MMP-2 is secreted in association with TIMP-2, which mediates cell surface binding of the latent complex [38]. Several proteases, MMP2, MT1-MMP, TIMP2, and integrin $\alpha_{\mathrm{v}} \beta_{3}$ were shown to colocalize in caveolae in human endothelial cells [39]. In this present study positive expression of TIMP-2 has been observed in tumors and also in normal tissues by means of ELISA and RT-PCR in both stage-II and stage-III cases. In line with our results Garbett E A et al. (2000) [40] showed increased expression of TIMP-2 in invasive breast cancer. In a previous study Ree A.H et al. 1997 correlated increased amount of TIMP-1 and TIMP-2 with distant metastasis [41]. So TIMP-2 may also play a crucial role in activation of MMP-2 in advanced stages of human breast cancer (Table 2).

The statistical analyses were carried out by using the Epi Info (TM) 3.5.3 software of the centers for disease Control and Prevention (CDC, USA) for windows 9.0 programme. The associations between MMP-2 expression and the regulating parameters of MMP-2 were tested. The univariate analyses were performed using chi-square analysis, and the independent prognostic value of variables was further examined with their corresponding Probability values.

Recently, the expression of MT1-MMP in various human cancer tissues has been associated with pro-MMP-2 activation. Deryugina et al. (2001), have demonstrated that MT1-MMP:TIMP2:MMP2: $\alpha_{\mathrm{v}} \beta_{3}$ complex was shown to promote maturation of MMP2 in carcinoma cells [42]. In our present study increased expression of MT1-MMP has been observed in tumor as compared to adjacent normal tissue, confirming its possible role in activation of MMP-2 in breast cancer. Extracellular matrix metalloproteinase inducer (EMMPRIN) (also known as CD 147) is a $58 \mathrm{kDa}$ glycoprotein, originally purified from the plasma membrane of cancer cells and was designated tumor collagenase stimulating factor (TCSF) because of its ability to stimulate collagenase-1 (MMP-1) synthesis by tumor stromal fibroblast cells [43]. In our present study, increased expression of EMPRIN has been observed in tumor tissue as compared to adjacent normal tissue, indicating its role in MMP-2 activation. VEGF has been identified as a predominant regulator of tumor angiogenesis. Expression of the VEGF ligand has been observed across a range of tumor types and has been widely correlated with tumor development and/or poor prognosis [44]-[48]. In ductal carcinoma in situ, increased pathologically aggressive lesions was associated with increased 
Table 2. Gelatinase expression and statistically significant clinicopathological variables of breast cancer patients in univariate analysis.

\begin{tabular}{cccc}
\hline Variables & High expression in tumor & High expression in normal tissue & P \\
\hline MMP-2 & 25 & 0 & 0.00001 \\
TIMP-2 & 17 & 8 & 0.0413 \\
MT1-MMP & 12 & 8 & 0.0374 \\
EMPRIN & 17 & 0 & 0.0001 \\
VEGF & 25 & 0 & 0.00001 \\
\hline
\end{tabular}

VEGF protein levels [49]. VEGF protein content is also increased in invasive breast cancer and this overexpression has prognostic significance in patients with either node-positive or node-negative disease for both relapsefree and overall survival. In patients with human epidermal growth factor receptor (HER)-2 overexpressing tumours, a higher VEGF content was demonstrated, confirming that VEGF is a downstream target of HER-2 activation. It is observed, that over expression of VEGF significantly correlated with MMP-2 expression and activity in various cancer types including breast cancer. In our present study, enhanced expression of VEGF protein has been observed in tumors, compared to adjacent normal tissues indicating its correlation with enhanced MMP-2 expression. In line with our result, Li Hao et al. (2007) has shown that VEGF and MMP-2 co-expression is associated with primary tumor progression, histological grade and lymph node status in patients of breast cancer. In a previous study from our lab, we investigated whether $\alpha_{\mathrm{v}} \beta_{3}$ and MMP-2 are associated on the membranes of a human cervical cell, SiHa and the possible involvement of MT1-MMP and TIMP-2 in the modulation of MMP-2 activity. SiHa cells expressed all the molecules which are reported to form a complex to activate pro-MMP-2. Active MMP-2 associated with $\alpha_{v} \beta_{3}$ may regulate matrix degradation and thereby modulate directed motility of SiHa cells. In this present study we confirm that breast cancer tissue shows more alfaVbeta3 associated MMP-2 compare to matched control tissue. The components of the MMP-2 activation complex (MT1-MMP, EMMPRIN, TIMP-2) and VEGF are all in increased amount in cancer tissues than the matched controls. The findings may help to understand the role of alfaVbeta3 intrgin associated MMP-2 in breast cancer progression. The findings may have potential use in clinical management of breast cancer.

\section{References}

[1] Albelda, S.M. (1993) Biology of the Disease. Role of Integrins and Other Cell Adhesion Molecules in Tumor Progression and Metastasis. Laboratory Investigation, 68, 4-17.

[2] Hynes, R.O. (1987) Integrins: A Family of Cell Surface Receptors. Cell, 48, 549-554. http://dx.doi.org/10.1016/0092-8674(87)90233-9

[3] Cheresh, D. (1993) Integrins, Structure, Function and Biological Properties. Advances in Molecular and Cell Biology, 6, 225-252. http://dx.doi.org/10.1016/S1569-2558(08)60204-0

[4] Guadango, T.M., Ohtsubo, M., Roberts, J.M. and Assoian, R.K. (1993) A Link between Cyclin A Expression and Adhesion Dependent Cell Proliferation. Science, 262, 1572-1575. http://dx.doi.org/10.1126/science.8248807

[5] Varner, J.A., Emerson, D.A. and Juliano, R.L. (1995) Integrin $\alpha 5 \beta 1$ Expression in Negatively Regulates Cell Growth: Reversal by Attachment to Fibronectin. Molecular Biology of the Cell, 6, 725-740. http://dx.doi.org/10.1091/mbc.6.6.725

[6] Juliano, R.L. and Haskill, S. (1993) Signal Transduction from the Extracellular Matrix. The Journal of Cell Biology, 120, 577-585. http://dx.doi.org/10.1083/jcb.120.3.577

[7] Montgomery, A.M.P., Reisfels, R.A. and Cheresh, D.A. (1994) Integrin $\alpha_{v} \beta_{3}$ Rescues Melanoma Cells from Apoptosis in Three Dimensional Dermal Collagen. Proceedings of the National Academy of Sciences of the United States of America, 91, 8856-8860. http://dx.doi.org/10.1073/pnas.91.19.8856

[8] Boudreau, N., Sympson, C.J. and Werb, Z. (1995) Bissel. Suppression of ICE and Appoptosis in Mammery Epithelial Cells by Extracellular Matrix. Science, 267, 891-893. http://dx.doi.org/10.1126/science.7531366

[9] Thomas, G.J., Jones, J., Speight, P.M. (1997) Integrin and Oral Cancer. Oral Oncology, 33, 381-388. http://dx.doi.org/10.1016/S0964-1955(97)00021-3

[10] Blanchine, P.J., Burd, P.R. and Metcalf, D.D. (1992) IL-3 Dependent Mast Cells Attach to Plate Bound Vitronectin. Demonstration of Augmented Proliferation in Response to Signals Transduced via Cell Surface Vitronectin Receptors. 
The Journal of Immunology, 149, 3665-3671.

[11] Albelda, S.M., Mette, S.A., Elder, D.E., Stewart, R., Damianovich, L., Herlyn, M. and Buck, C.A. (1990) Integrin Distribution in Malignant Melanoma: Association of the $\beta 3$ Subunit with Tumor Progression. Cancer Research, 50, 67576764.

[12] Lafrenie, R.M., Podor, T.J., Buchanan, M.R. and Orr, F.W. (1992) Upregulated Biosynthesis and Expression of Endothelial Cell Vitronectin Receptor Enhances Cancer Cell Adhesion. Cancer Research, 52, 2202-2208.

[13] Marchall, J.F., Nesbitt, S.A., Helfrich, M.H., Horton, M.A., Palakova, K. and Hart, I.R. (1991) Integrin Expression in Human Melanoma Cell Lines: Heterogenicity of Vitronectin Receptor Composition and Function. International Journal of Cancer, 49, 924-931. http://dx.doi.org/10.1002/ijc.2910490621

[14] Monsky, W.L., Kelly, T., Lin, C.Y., Yeh, Y., Stetler-Stevenson, W.G., Mueller, S.C. and Chen, W.T. (1993) Binding and Localization of M(r) 72,000 Matrix Metalloproteinase at Cell Surface Invadopodia. Cancer Research, 53, 31593164.

[15] Partridge, C.A., Phillips, P.G., Niedbala, M.J. and Jeffrey, J.J. (1997) Localization and Activation of Type IV Collagenase/Gelatinase at Endothelial Focal Contacts. American Journal of Physiology, 272, L813-L822.

[16] Koyama, S. (2004) Enhanced Cell Surface Expression of Matrix Metalloproteinases and Their Inhibitors, and TumorInduced Host Response in Progression of Human Gastric Carcinoma. Digestive Diseases and Sciences, 49, 1621-1630. http://dx.doi.org/10.1023/B:DDAS.0000043375.35611.dd

[17] Brooks, P.C., Stromblad, S., Sanders, L., Von Schalscha, T.L., Aimes, R.T., Stetlar-Stevenson, W.G., Quigley, J.P. and Chesesh, D.A. (1996) Localization of Matrix Metalloproteinase-2 to the Surface of Invasive Cells by Interaction with $\alpha v \beta 3$. Cell, 85, 683-693. http://dx.doi.org/10.1016/S0092-8674(00)81235-0

[18] Brooks, P.C., Silletti, S., Von Schalscha, T.L., Friedlander, M. and Cheresh, D.A. (1998) Disruption of Angiogenesis by PEX, a Noncatalytic Metalloproteinase Fragment with Integrin Binding Activity. Cell, 92, 391-400. http://dx.doi.org/10.1016/S0092-8674(00)80931-9

[19] Liotta, L.A. and Stetler-Stevenson, W.G. (1990) Metalloproteinases and Cancer Invasion. Seminars in Cancer Biology, 1, 99-106.

[20] Monteagudo, C., Merino, M.J., San-Juan, J., Liotta, L.A. and Stetler-Stevenson, W.G. (1990) Immunohistochemical Distribution of Type IV Collagenase in Normal, Benign, and Malignant Breast Tissue. American Journal of Pathology, 136, 585-592.

[21] D’Errico, A., Garbisa, S., Liotta, L.A., Castronovo, R., Stetler-Stevenson, W. and Grigioni, W.F. (1991) Augmentation of Type IV Collagenase and Laminin Receptors Immunoreactivity Associated with Human Breast, Colon and Gastric Carcinoma Progression. Modern Pathology, 4, 239-246.

[22] Chattopadhyay, N. and Chatterjee, A. (2001) Studies on the Expression of Alpha(v)Beta3 Integrin Receptors in Non-Malignant and Malignant Human Cervical Tumor Tissues. Journal of Experimental \& Clinical Cancer Research, 20, 269-275.

[23] Zhao, Y., Bachelier, R., Treilleux, I., Pujuguet, P., Peyruchaud, O., Baron, R., Clément-Lacroix, P. and Clézardin, P. (2007) Tumor $\alpha_{\mathrm{v}} \beta_{3}$ Is a Therapeutic Target for Breast Cancer Bone Metastasis. Cancer Research, 67, 5821-5830. http://dx.doi.org/10.1158/0008-5472.CAN-06-4499

[24] Seftor, R.E., Seftor, E.A., Stetler Stevenson, W.G. and Hendrix, M.J.C. (1993) The 72 kD Type IV Collagenase Is Modulated via Differential Expression of $\alpha_{\mathrm{v}} \beta_{3}$ and $\alpha_{5} \beta_{1}$ Integrins in Human Melanoma Cell Invasion. Cancer Research, 53, 3411-3415.

[25] Philippe, C. (2011) Therapeutic Targets for Bone Metastases in Breast Cancer. Breast Cancer Research, 13, 207. http://dx.doi.org/10.1186/bcr2835

[26] Felding-Habbermann, B., Fransvea, E., O’toole, T.E., Manzuk, L., Faha, B. and Hensler, M. (2002) Involvement of Tumor Cell Integrin $\alpha_{v} \beta_{3}$ in Hemaogenous Metastasis of Human Melanoma Cells. Clinical and Experimental Metastasis, 19, 427-436. http://dx.doi.org/10.1023/A:1016377114119

[27] Gehlsen, K.R., Davis, G.E. and Sriramarao, P. (1992) Integrin Expression in Human Melanoma Cells with Differing Invasive and Metastatic Properties. Clinical and Experimental Metastasis, 10, 111-120. http://dx.doi.org/10.1007/BF00114587

[28] Nip, J., Shibata, H., Loskutoff, D.J., Cheresh, D.A. and Brodt, P. (1992) Human Melanoma Cells Derived from Lymphatic Metastases Use Alpha-V Beta-3 to Adhere to Lymph Node Vitronectin. Journal of Clinical Investigation, 90, 1406-1413. http://dx.doi.org/10.1172/JCI116007

[29] Gasparini, G, Brooks, P.C., Beganzoli, E., Vermulen, P.B., Bonoldi, E., Dirx, L.Y., Ranjeri, G., Miceli, R. and Cheresh, D.A. (1998) Vascular Integrin $\alpha_{\mathrm{v}} \beta_{3}$ : A New Prognostic Indicator in Breast Cancer. Clinical Cancer Research, 4, 26252624. 
[30] Brooks, P.C., Stromblad, S., Klemke, R., Vissocher, D.F., Sarkar, H. and Cheresh, D.A. (1995) Antiintegrin $\alpha_{v} \beta_{3}$ Blocks Human Breast Cancer Growth and Angiogenesis in Human Skin. Journal of Clinical Investigation, 96, 18151822. http://dx.doi.org/10.1172/JCI118227

[31] Davies, B., Miles, D.W., Happerfield, L.C., Naylor, M.S., Bobrow, L.G., Rubens, R.D. and Balkwill, F.R. (1993) Activity of Type IV Collagenases in Benign and Malignant Breast Disease. British Journal of Cancer, 67, 1126-1133. http://dx.doi.org/10.1038/bjc.1993.207

[32] Tryggvason, K., Höyhtyä, M. and Pyke, C. (1993) Type IV Collagenase in Invasive Tumors. Breast Cancer Research and Treatment, 24, 209-218. http://dx.doi.org/10.1007/BF01833261

[33] Talvensaari-Mattila, A., Pääkkö, P., Höyhtyä, M., Blanco-Sequeiros, G. and Turpeenniemi-Hujanen, T. (1998) Matrix Metalloproteinase-2 Immunoreactive Protein, a Marker of Aggressiveness in Breast Carcinoma. Cancer, 83, 11531162. http://dx.doi.org/10.1002/(SICI)1097-0142(19980915)83:6<1153::AID-CNCR14>3.0.CO;2-4

[34] Hoodn, J.D. and Cheresh, D.A. (2002) Role of Integrins in Cell Invasion and Migration. Nature Reviews Cancer, 2, 91-100. http://dx.doi.org/10.1038/nrc727

[35] Lisa, M., Bafetti Timothy, N., Young, Yoshifumi, I. and Sharon Stack, M. (1998) Intact Vitronectin Induces Matrix Metalloproteinase-2 and Tissue Inhibitor of Metalloproteinases-2 Expression and Enhanced Cellular Invasion by Melanoma Cells. Journal of Biological Chemistry, 273, 143-149. http://dx.doi.org/10.1074/jbc.273.1.143

[36] Nguyen, M., Arkell, J. and Jackson, C.J. (2000) Activated Protein C Directly Activates Human Endothelial Gelatinase A. Journal of Biological Chemistry, 275, 9095-9098. http://dx.doi.org/10.1074/jbc.275.13.9095

[37] Morrison, C.J., Butler, G.S., Bigg, H.F., Roberts, C.R., Soloway, P.D. and Overall, C.M. (2001) Cellular Activation of MMP-2 (Gelatinase A) by MT2-MMP Occurs via a TIMP-2-Independent Pathway. Journal of Biological Chemistry, 276, 47402-47410. http://dx.doi.org/10.1074/jbc.M108643200

[38] Zahradka, P., Harding, G., Litchie, B., Thomas, S., Werner, J.P., Wilson, D.P. and Yurkova, N. (2004) Activation of MMP-2 in Response to Vascular Injury Is Mediated by Phosphatidylinositol 3-Kinase-Dependent Expression of MT1MMP. American Journal of Physiology: Heart and Circulatory Physiology, 287, H2861-H2870. http://dx.doi.org/10.1152/ajpheart.00230.2004

[39] Corcoran, M.L., Emmert-Buck, M.R., McClanahan, J.L., Pelina-Parker, M. and Stetler-Stevenson, W.G. (1996) TIMP2 Mediates Cell Surface Binding of MMP-2. Advances in Experimental Medicine and Biology, 389, 295-304. http://dx.doi.org/10.1007/978-1-4613-0335-0_36

[40] Puyraimond, A., Fridman, R., Lemesle, M., Arbeille, B. and Menashi, S. (2001) MMP-2 Colocalizes with Caveolae on the Surface of Endothelial Cells. Experimental Cell Research, 262, 28-36. http://dx.doi.org/10.1006/excr.2000.5069

[41] Garbett, E.A., Reed, M.W., Stephenson, T.J. and Brown, N.J. (2000) Proteolysis in Human Breast Cancer. Molecular Pathology, 53, 99-106. http://dx.doi.org/10.1136/mp.53.2.99

[42] Ree, A.H., Florenes, V.A., Berg, J.P., Maelandsmo, G.M., Nesland, J.M. and Fodstad, O. (1997) High Levels of Messenger RNAs for Tissue Inhibitors of Metalloproteinases (TIMP-1 and TIMP-2) in Primary Breast Carcinomas Are Associated with Development of Distant Metastases. Clinical Cancer Research, 3, 1623-1628.

[43] Deryugina, E.I., Ratnikov, B., Monosov, E., Postnova, T.I., Discipio, R., Smith, J.W. and Strongin, A.Y. (2001) MT1-MMP Initiates Activation of Pro-MMP-2 and Integrin $\alpha_{\mathrm{v}} \beta_{3}$ Promotes Maturation of MMP-2 in Breast Carcinoma Cells. Experimental Cell Research, 263, 209-223. http://dx.doi.org/10.1006/excr.2000.5118

[44] Ellis, S.M., Nabeshima, K. and Biswas, C. (1989) Monoclonal Antibody Preparation and Purification of a Tumor Cell Collagenase Stimulatory Factor. Cancer Research, 49, 3385-3391.

[45] Guo, H., Zucke, R.S., Gordon, M.K., Toole, B.P. and Biswas, C. (1997) Stimulation of Matrix Metalloproteinase Production by Recombinant Extracellular Matrix Metalloproteinase Inducer from Transfected Chinese Hamster Ovary Cells. Journal of Biological Chemistry, 272, 24-27. http://dx.doi.org/10.1074/jbc.272.1.24

[46] Kataoka, H., DeCastro, R., Zucker, S. and Biswas, C. (1993) Tumor Cell-Derived Collagenase-Stimulatory Factor Increases Expression of Interstitial Collagenase, Stromelysin, and 72-kDa Gelatinase. Cancer Research, 53, 3154-3158.

[47] Sameshima, T., Nabeshima, K., Toole, B.P., Yokogami, K., Okada, Y., Goya, T., Koono, M. and Wakisaka, S. (2000) Glioma Cell Extracellular Matrix Metalloproteinase Inducer (EMMPRIN) (CD147) Stimulates Production of Membrane-Type Matrix Metalloproteinases and Activated Gelatinase A in Co-Cultures with Brain-Derived Fibroblasts. Cancer Letters, 157, 177-184. http://dx.doi.org/10.1016/S0304-3835(00)00485-7

[48] Chattopadhyay, N., Mitra, A., Frei, E. and Chatterjee, A. (2001) Human Cervical Tumor Cell (Siha) Surface $\alpha_{\mathrm{v}} \beta_{3}$ Integrin Receptor Has Associated Matrix Metalloproteinase (MMP-2) Activity. Journal of Cancer Research and Clinical Oncology, 127, 653-658. http://dx.doi.org/10.1007/s004320100271

[49] Mitra, A., Chakrabarti, J., Chattopadhyay, N. and Chatterjee, A. (2003) Membrane-Associated MMP-2 in Human Cervical Cancer. Journal of Environmental Pathology, Toxicology and Oncology, 22, 93-100. 